\title{
Bacteremia due to Weeksella virosa in a pediatric patient with embryonal rhabdomyosarcoma
}

\author{
Denisse N. Vaquera-Aparicio ${ }^{1}$, Abiel H. Mascareñas-De los Santos ${ }^{1}$, Néstor Casillas-Vega ${ }^{2}$, \\ Patricia Riojas-Hernández ${ }^{1}$, Jorge Llaca-Díaz², Ismael Herrera-Benavente ${ }^{3}$ and José I. Castillo-Bejarano ${ }^{1 *}$ \\ ${ }^{1}$ Servicio de Enfermedades Infecciosas, Departmento de Pediatría, Hospital Universitario Dr. José Eleuterio González, Monterrey, Nuevo León; \\ ${ }^{2}$ Departmento de Patología Clínica, Departmento de Microbiología Clínica, Hospital Universitario Dr. José Eleuterio González, Monterrey; ${ }^{3}$ Departmento \\ de Microbiología, Facultad de Medicina, Universidad Autónoma de San Luis Potosí, San Luis Potosí. Mexico
}

\begin{abstract}
Background: Weeksella virosa is one of the two species of the genus Weeksella. Clinical disease due to this bacterium in humans is rare, for which only nine cases have been reported in the literature. Case report: A 4-year-old male patient was diagnosed with a left orbit rhabdomyosarcoma Stage III and was admitted to a northeast third level referral center in Mexico. Aerobic, non-pigmented, Gram-negative rod was isolated from a blood culture. W. virosa was identified by Sensititre ${ }^{\mathrm{TM}}$ ARIS. This organism has been described in cases of spontaneous bacterial peritonitis, sepsis, pneumonia, ventriculitis, and urinary tract infection. Conclusions: Clinicians should consider the diagnosis of W. virosa bacteremia in cases involving immunocompromised patients with oral lesions, although it is infrequent. To the best of our knowledge, this is the first clinical report of $W$. virosa bacteremia described in an immunocompromised pediatric patient.
\end{abstract}

Key words: Bacteremia. Neutropenia. Mucositis.

\section{Bacteriemia por Weeksella virosa en un paciente pediátrico con rabdomiosarcoma embrionario}

\section{Resumen}

Introducción: Weeksella virosa es una de las dos especies del género Weeksella. En los humanos, los reportes de infección por este microorganismo son raros. Solo se han reportado nueve casos en la literatura. Caso clínico: Paciente masculino de 4 años con diagnóstico de rabdomiosarcoma embrionario de órbita izquierda en estadio III, que fue atendido en un hospital de tercer nivel en el noreste de México. Se realizó un hemocultivo, a partir del cual se aisló un bacilo gramnegativo aerobio, no pigmentado. Se identificó W. virosa mediante Sensititre ${ }^{\mathrm{TM}}$ ARIS. Este microorganismo ha sido descrito en casos de peritonitis bacteriana espontánea, sepsis, neumonía, ventriculitis e infección del tracto urinario. Conclusiones: Aunque los casos de bacteriemia por W. virosa son raros, los clínicos deben considerar este agente en pacientes inmunocomprometidos con lesiones orales. Hasta donde se conoce, este es el primer caso que se describe de bacteriemia por W. virosa en un paciente pediátrico inmunocomprometido.

Palabras clave: Bacteriemia. Neutropenia. Mucositis.

\section{Correspondence:}

*José Iván Castillo Bejarano

E-mail: jicastillobejarano@gmail.com

Available online: 19-05-2020

Date of reception: 16-12-2019 Date of acceptance: 11-03-2020 DOI: 10.24875/BMHIM.20000205
Bol Med Hosp Infant Mex. 2020;77(3):149-152

www.bmhim.com 1665-1146/@ 2020 Hospital Infantil de México Federico Gómez. Published by Permanyer. This is an open access article under the CC BY-NC-ND license (http://creativecommons.org/licenses/by-nc-nd/4.0/). 


\section{Introduction}

Weeksella virosa (W. virosa) is one of the two species of the genus Weeksella and belongs to the family Flavobacterium; it was named in honor of O.B. Weeks for his contributions to the taxonomy ${ }^{1}$. Strains of W. virosa have been detected in the genitourinary tract, oral cavity, rectal area, middle ear, mastoid, and cerebrospinal fluid by culture methods ${ }^{2}$. Holmes et al. found $72.3 \%$ of the strains in urine samples or genitourinary tract ${ }^{3}$. Clinical disease in humans is rare; only nine cases have been reported. The most common clinical syndrome is characterized by spontaneous bacterial peritonitis, although sepsis, pneumonia, ventriculitis, and urinary tract infection have been described. Among the nine cases reported, only the one reported by Manoragan et al. describes $W$. virosa as a cause of death in a 53-year-old patient with lymphoma ${ }^{4}$.

In the present study, the first clinical report of bacteremia due to $W$. virosa in an immunocompromised pediatric patient is described.

\section{Clinical case}

A 4-year-old male patient diagnosed as a Stage III left orbit rhabdomyosarcoma in 2016 - with left orbital enucleation in 2018 and multiple hospitalizations due to neutropenic fever - was admitted to Hospital Universitario Dr. José Eleuterio González in June 2019. The patient received a last dose of chemotherapy with ifosfamide, mesna, carboplatin, and etoposide 10 days before admission.

The patient started with a fever $\left(38.6^{\circ} \mathrm{C}\right)$, cough, and odynophagia, accompanied by diarrheic evacuations. A physical examination showed a $38^{\circ} \mathrm{C}$ fever and a $100 /$ min heart rate. Pharyngeal erythema was detected, as well as hypertrophic tonsils and hyperemic left tympanic membrane with hyaline rhinorrhea. According to the protocol for fever and neutropenia in children, imipenem/cilastatin was initiated within the first hour of admission, and a sample for blood culture was collected. The laboratory tests revealed severe neutropenia $\left(200 \mathrm{cells} / \mathrm{mm}^{3}\right)$ and C-reactive protein values of $24 \mathrm{mg} / \mathrm{dl}$.

The patient showed a favorable clinical course with remission of the respiratory symptoms and fever on days 2 and 3 of hospital stay, respectively. The remission of neutropenia was documented after four days. Lab test results were as follows: hemoglobin, $9.93 \mathrm{~g} / \mathrm{dl}$; white blood cell count (WBC), 1.56 cells $/ \mathrm{mm}^{3}$; neutrophils (Neu), 0.756 cells $/ \mathrm{mm}^{3}$; and platelets, 43.6 cells $/ \mathrm{mm}^{3}$. Blood culture was processed in a VersaTREK REDOX 1 aerobic EZ Draw $40 \mathrm{ml}$ bottle (ThermoFisher, Scientific). Gram staining of blood culture broth revealed Gram-negative rods. Meropenem was initiated due to its better activity against Pseudomonas aeruginosa and Acinetobacter baumannii, which are agents of high prevalence in this institution. The broth was plated on blood, chocolate, and MacConkey agar and incubated in aerobiosis. Subsequent examination of the plates revealed abundant growth of colonies on blood agar. The growth in MacConkey agar was found negative. The identification was performed by Sensititre ${ }^{\mathrm{TM}}$ ARIS $^{\mathrm{TM}} 2 \mathrm{X}$ ID/AST System-Thermo Fisher Scientific, which reported W. virosa. The pathogen was susceptible to amikacin, gentamicin, ampicillin, cefuroxime, ciprofloxacin, piperacillin/tazobactam, and tetracyclines.

After 10 days of treatment with intravenous meropenem, outpatient management was indicated with ciprofloxacin for 14 days, with favorable results.

\section{Discussion}

Weeksella species named Flavobacterium genitale initially due to its preponderance for the urogenital tract are oxidase-positive and catalase-positive Gramnegative rod, which are unable to grow on MacConkey agar ${ }^{1}$. The organism will grow on blood and chocolate agar after $48 \mathrm{~h}$ of incubation at $22^{\circ} \mathrm{C}, 36^{\circ} \mathrm{C}$, and $42^{\circ} \mathrm{C}$. Culture will reveal $2 \mathrm{~mm}$ of diameter cream-colored and intensely mucous colonies, with an appearance of yellow tinge secondary to a non-diffusible pigment ${ }^{2,5}$.

Two species of Weeksella have been identified: W. virosa and Weeksella zoohelcum ${ }^{2}$. The latter species have been isolated from human wounds caused by animal bites.

The overall incidence of this bacterium - documented by Holmes et al. ${ }^{3}$ in the urogenital tract - was $2 \%$ of the female population, with a higher incidence in a group exposed to sexually transmitted diseases ${ }^{6}$. More recent reports have shown a varying incidence from 0.42 to $15 \%{ }^{6}$.

Since 1970, clinical cases of $W$. virosa have rarely been isolated. In a literature search between 1990 and 2019 , nine cases with $W$. virosa infection were found (Table 1). A review of these cases revealed the following clinical syndromes: spontaneous bacterial peritonitis (2/9), sepsis (2/9), urinary tract infection (2/9), pneumonia (1/9), and surgical head wound infection with ventriculitis (1/9), amnionitis (1/9), and wound 
Table 1. Weeksella virosa case series

\begin{tabular}{|c|c|c|c|c|c|c|c|c|}
\hline Author & Year & Age & Sex & Comorbidities & Source & $\begin{array}{l}\text { Clinical } \\
\text { syndrome }\end{array}$ & Treatment & Outcome \\
\hline Faber et al. ${ }^{11}$ & 1991 & 33 & $\mathrm{~F}$ & ESRF on PD & Peritoneal fluid & SBP & $\begin{array}{l}\text { Imipenem, } \\
\text { cilastatin }\end{array}$ & Survived \\
\hline Boixeda et al. ${ }^{12}$ & 1998 & 55 & M & HCV, cirrhosis & Peritoneal fluid & SBP & Cefoxitin & Survived \\
\hline Meharwal et al. ${ }^{13}$ & 2002 & NR & NR & NR & Urine & UTI & NR & NR \\
\hline Manoragan et al. ${ }^{4}$ & 2004 & 53 & $\mathrm{~F}$ & $\begin{array}{l}\text { Lymphoma, DM, ESRF on } \\
\text { HD }\end{array}$ & Blood, sputum & Pneumonia & $\begin{array}{l}\text { Cefepime, } \\
\text { vancomycin }\end{array}$ & Died \\
\hline \multirow[t]{4}{*}{ Slenker et al. ${ }^{8}$} & 2012 & 44 & $\mathrm{~F}$ & Obesity, menorrhagia & Wound & Sepsis & $\begin{array}{l}\text { Incision and } \\
\text { drainage }\end{array}$ & Survived \\
\hline & & 31 & $\mathrm{~F}$ & $\begin{array}{l}\text { IHD, ESRF, HCV, obesity, } \\
\text { asthma }\end{array}$ & Blood & $\begin{array}{l}\text { Labial wound } \\
\text { infection }\end{array}$ & $\begin{array}{l}\text { Aztreonam, } \\
\text { tobramycin }\end{array}$ & Died \\
\hline & & 25 & $\mathrm{~F}$ & $\begin{array}{l}\text { Spontaneous vaginal } \\
\text { delivery }\end{array}$ & Placenta & Amnionitis & $\begin{array}{l}\text { Ampicillin, } \\
\text { gentamicin }\end{array}$ & Survived \\
\hline & & 26 & $\mathrm{~F}$ & $\begin{array}{l}\text { Endometriosis, } \\
\text { abdominopelvic } \\
\text { adhesiolysis, DM }\end{array}$ & Urine & UTI & $\begin{array}{l}\text { Trimethoprim- } \\
\text { sulfamethoxazole }\end{array}$ & Survived \\
\hline Toescu et al. ${ }^{14}$ & 2017 & 50 & $\mathrm{~F}$ & $\begin{array}{l}\text { Anaplastic meningioma, } \\
\text { glucocorticoid use, WBRT }\end{array}$ & $\begin{array}{l}\text { Cranial wound, } \\
\text { brain ventricle }\end{array}$ & $\begin{array}{l}\text { Craniotomy } \\
\text { wound } \\
\text { infection, } \\
\text { ventriculitis }\end{array}$ & $\begin{array}{l}\text { Ceftriaxone, } \\
\text { amoxicillin }\end{array}$ & Survived \\
\hline Current report & 2019 & 4 & M & $\begin{array}{l}\text { Embryonal } \\
\text { rhabdomyosarcoma }\end{array}$ & Blood & Bacteremia & $\begin{array}{l}\text { Imipenem, } \\
\text { meropenem }\end{array}$ & Survived \\
\hline
\end{tabular}

F: female; M: male; ESRF: end-stage renal failure; PD: peritoneal dialysis; SBP: spontaneous bacterial peritonitis; HCV: hepatitis C virus; NR: not reported; UTI: urinary tract infection; DM: diabetes mellitus; HD: hemodialysis; IHD: ischemic heart disease; WBRT: whole-brain radiotherapy.

Modified from Slenker et al. ${ }^{6}$

infection (1/9). Six of the ten cases, including the current case, were found during the past decade, probably indicating an increased incidence of this organism in humans. At present, no risk factors have been implied, but all of the patients showed at least one comorbidity, including diabetes mellitus (2/9), end-stage renal disease (3/9), hepatitis $C$ virus infection (1/9), ischemic heart disease (1/10), lymphoma (1/9), or anaplastic meningioma (1/9). Of the ten cases, this organism was isolated from two blood cultures in patients with lymphoma and hepatitis $C$ virus infection, respectively. Tatum et al. documented two of 76 blood Group I organism isolates in the Centers for Disease Control and Prevention between 1947 and 1973. However, the clinical features in these cases were not documented, although success was reported in five of nine patients ${ }^{7}$. In comparison to the current case, a correlation between the site of infection and the symptoms presented is described. In one case, a fatal outcome occurred with the involvement of $W$. virosa in pneumonia ${ }^{8}$.

No species-specific testing standards exist for this organism; however, the Clinical and Laboratory
Standards Institute susceptibility testing interpretative standard table for other non-Enterobacteriaceae Gramnegative rods can be used ${ }^{9}$. Resistance has been noted in vitro with aminoglycosides, nalidixic acid, and nitrofurantoin ${ }^{10,11}$. According to previous reports, our institutional protocol represents a viable coverage for W. virosa. Until the present day, only two deaths associated with W. virosa have been reported: in one case, the initial empirical treatment was not effective for W. virosa, and the second case was a patient with multiple comorbidities.

The present report describes a patient with bacteremia, who presented a neutropenic fever episode. The initial choice of antimicrobial treatment was imipenem/ cilastatin, according to the Infectious Diseases Society of America (IDSA) guidelines for the use of antimicrobial agents in neutropenic patients with cancer. For fever and neutropenia, IDSA guidelines suggest the empirical treatment with cefepime, piperacillin/tazobactam, or imipenem/cilastatin. However, the identification of new pathogens with recent technology would be an opportunity to review the standard treatment. The 
patient survived the episode and was discharged fully recovered from the hospital. To the best of our knowledge, this is the first case of $W$. virosa bacteremia documented in Mexico, and the first pediatric case reported. Furthermore, not only adults but also children with comorbidities, such as renal disease, liver disease, or oncology disease, should be considered a high-risk population for $W$. virosa infection.

In conclusion, this is the first case of $W$. virosa bacteremia in a pediatric patient with embryonal rhabdomyosarcoma. The identification of new pathogens by molecular techniques should be an opportunity to reassess the empirical therapies established so far.

\section{Ethical disclosures}

Protection of human and animal subjects. The authors declare that no experiments were performed on humans or animals for this study.

Confidentiality of data. The authors declare that they have followed the protocols of their work center on the publication of patient data.

Right to privacy and informed consent. The authors have obtained the written informed consent of the patients or subjects mentioned in the article. The corresponding author has this document.

\section{Conflicts of interest}

The authors declare no conflicts of interest.

\section{Funding}

None.

\section{References}

1. Martínez TM, Ovalle SA. Weeksella virosa. Rev Chil Infect. 2011; 28:429-30.

2. Lang E, Teshima H, Lucas S, Lapidus A, Hammon N, Deshpande S, et al. Complete genome sequence of Weeksella virosa type strain (9751). Stand Genomic Sci. 2011;4:81-90.

3. Holmes B, Steigerwalt AG, Weaver RE, Brenner DJ. Weeksella virosa gen. no v., sp. nov. (formerly group IIF), found in human clinical specimens. Syst Appl Microbiol. 1986;8:185-90.

4. Manoragan M, Marnejon T, Sarac E. Pneumonia and sepsis due to Weeksella virosa in an immunocompromised patient. Infect Dis Clin Pract. 2004;12:286-7.

5. Price K, Pickett M. Studies of clinical isolates of flavobacteria. In: Reichenbach $\mathrm{H}$, Weeks O, editors. The Flavobacterium-Cytophaga Group. Weinheim: Verlag Chemie; 1981. p 63-77.

6. Reina J, Gil J, Alomar P. Isolation of Weeksella virosa (formerly CDC group IIF) from a vaginal sample. Eur J Clin Microbiol Infect Dis. 1989;8:569-70.

7. Tatum HW, Ewing WH, Weaver RE. Miscellaneous gram-negative bacteria. In: Lennette EH, Spaulding EH, Truant JP, editors. Manual of Clinical Microbiology. Washington, DC: American Society for Microbiology; 1974. p. 270-94.

8. Slenker AK, Hess BD, Jungkind DL, DeSimone JA. Fatal case of Weeksella virosa sepsis. J Clin Microbiol. 2012;50:4166-7.

9. Clinical and Laboratory Standards Institute. Methods for Dilution Antimicrobial Susceptibility Tests for Bacteria that Grow Aerobically. CLSI Document M07-A9. Wayne, PA: Clinical and Laboratory Standards Institute; 2012.

10. Fass RJ, Barnishan J. In vitro susceptibilities of nonfermentative gram-negative bacilli other than Pseudomonas aeruginosa to 32 antimicrobial agents. Rev Infect Dis. 1980;2:841-53.

11. Faber MD, Del Busto R, Cruz C, Mezger E. Response of Weeksella virosa peritonitis to imipenem/cilastin. Adv Perit Dial. 1991;7:133-4.

12. Boixeda D, De Luis DA, Meseguer MA, Aller R, Martin de Argila C, Lopez Sanroman A. A case of spontaneous peritonitis caused by Weeksella virosa. Eur J Gastroenterol Hepatol. 1998;10:897-8.

13. Meharwal SK, Taneja N, Sharma SK, Sharma M. Complicated nosocomial UTI caused by nonfermenters. Indian J Urol. 2002;18:123-8.

14. Toescu S, Low HL, Lacey S. First report of postoperative intracranial Weeksella virosa infection. Acta Neurochir. 2017;159:1-4. 